\title{
IoT Monitory System Based Smart Trash Management
}

\author{
R. Krishna Bharathi, T. Selva Banupriya, Jeyapriyanga S
}

\begin{abstract}
The Internet of Things (IoT), as the anticipated infrastructure for the planned Smart City idea, offers fresh opportunities for city management. IoT vision presents promising and cost-effective alternatives for huge information collection and analysis that can be implemented in many areas, making them more efficient to operate. In this paper, we discuss one of Smart City's most difficult problems-municipal waste collections. We use our own genetic algorithm application to optimize the waste collection logistics process. The solution submitted offers calculation of more effective paths for garbage trucks. As an output, we provide a set of specified area-focused simulations.
\end{abstract}

Keywords : Raspberry Pi, IOT, Smart trash Bins, Sensors, garbage.

\section{INTRODUCTION}

In this paper, we present an answer about the Smartbin is a dustbin organize that incorporates the idea of IoT with the distributed computing of the Wireless Sensor Network. When this framework was quickly recognized, Microcontroller was utilized as an interface between the sensor plot and the GSM/GPRS system[1],[3],[5]. For the required information connected to the particular degree of waste at unmistakable spots, an android application is made to screen and incorporate. This is enused greenish in the setting and backing for swachhbharat for neatness. The circumstance of tidiness in regards to squander the board has turned out to be basic with populace proliferation. Waste the board includes, together with reconnaissance and guideline, arranging, accumulation, transport, treatment, reusing and transfer of waste. The present waste administration conspire, where the waste is accumulated every day from the streets, houses and different organizations, can't deal with the waste delivered effectively[2],[4],[6].

A model is proposed in this paper to screen the trash level of the particular trash receptacles progressively and to distinguish the level when the edge worth is come to by consolidating Sensors and Raspberry pi[7],[9],[11]. Utilizing the WiFi module, this data will be sent to the control unit and refreshed on schedule, contingent upon which improved way for Garbage Collecting Van (GCV) must be discovered, denying fuel utilization, cost, time and work. The data will be given whether the waste is completely isolated by a wet sensor

Revised Manuscript Received on August 22, 2019.

R.KrishnaBharathi, Department of Computer science and Engineering, Bharath Institute of Higher Education and Research, Chennai, Tamilnadu, India.Email: kribharamalingam94@gmail.com

T. SelvaBanupriya, Department of Computer science and Engineering, Bharath Institute of Higher Education and Research, Chennai, Tamilnadu, India.Email: priya8517@gmail.com

Jeyapriyanga $\mathbf{S}$, Department of Computer science and Engineering, Bharath Institute of Higher Education and Research, Chennai, Tamilnadu, India.Email: jani28cse@gmail.com and a mugginess sensor that reuses, dispense with and reuse waste.Qualitative investigation will be performed to create reports utilizing data mining. The essential objective of this plan to be acquainted is with supplant the current dull framework that will enable the town to turn into a savvy city.

\section{EXISTING SYSTEM}

The current scheme is resource-consuming and ineffective as overflowing and stinking dustbins become more of a issue than a solution. In the current system trash is gathered once or twice a week by corporation. Although the trash stinks and overflows the garbage bins, spreading through the highways and polluting the atmosphere. Street dogs and livestock are eating the waste meat and speeding across the region, creating a filthy atmosphere[8],[10],[12].

The sensors positioned in the bin at the top stage in the current scheme sense the amount of the trash in that bin. When the limit is reached, a command is produced and sent to the central office through the trash collection notification Zig-Bee technology. The smell is going to be heavy, causing air pollution and spreading disease. Street dogs and livestock are eating the waste meat and speeding across the region, creating a filthy atmosphere. The sensors positioned in the bin at the top stage in the current scheme sense the amount of the trash in that bin[13],[15],[17].The central office authority transmits this notification through the GSM module to the garbage collection van. GSM is interfaced with the ARM microcontroller which controls compatibility between the GSM modem and the ARM microcontroller.

\section{PROPOSED SYSTEM}

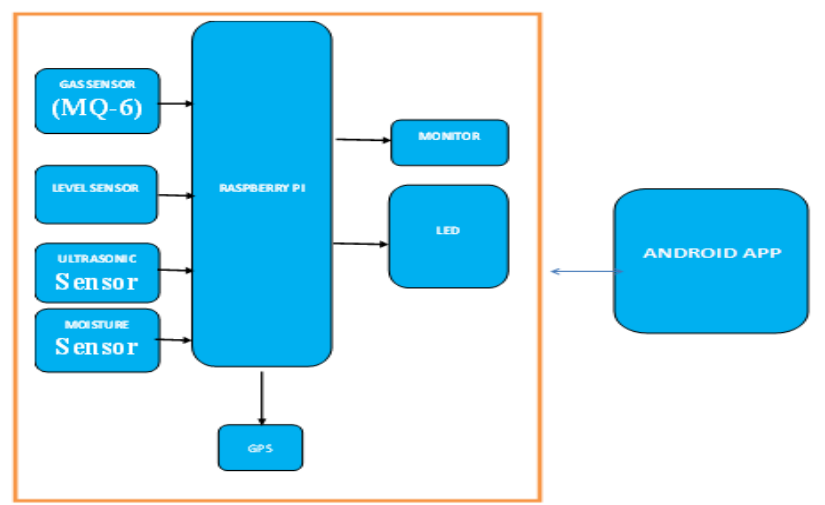

Figure - 1 System Architecture

The architecture suggested will have a dustbins master slave setup. In distant regions, this would solve the connectivity problems. These slave 
dustbins interact with their respective master dustbins their data. A microcontroller shall be provided for each master dustbin.

Raspberry Pi-Chip: Broadcom BCM2837 SOC Core Architecture: ARM11 CPU: 1.2 GHZ Application Processor Low Power ARM1176JZFS. Gives prominent deciphering of Open GL ES 2.0, equipment quickened Open VG, and $1080 \mathrm{p} 30 \mathrm{H} .264$. Equipped for $1 \mathrm{Gpixel} / \mathrm{s}$, $1.5 \mathrm{Gtexel} / \mathrm{s}$ or 24GFLOPs with surface sifting and DMA framework Memory: 1 GB SDRAM GPIO Connector: 40-stick $2.54 \mathrm{~mm}$ (100 mil) extension header: 2x20 strip Offering 27 GPIO sticks just as inventory line $+3.3 \mathrm{~V},+5 \mathrm{~V}$ and GND. Working System: Micro SD card boots running a working framework form of Linux. Offering 27 GPIO sticks just as stockpile line $+3.3 \mathrm{~V},+5 \mathrm{~V}$ and GND. Working System: Micro SD card boots running a working framework rendition of Linux.

Gas Sensor: With an electro-chemical sensor, the MQ series of gas sensors use a tiny heater inside. They are susceptible to a variety of gasses and are used at room temperature indoors.

Level Sensor: A level sensor is a tool used to determine the level or quantity of fluids, liquids or other substances flowing through an open or closed system. Continuous level sensors are used to measure concentrations to a particular threshold, but precise findings are provided[14],[16],[18].

Ultrasonic Sensor: According to the current creation, the diagnostic system and the diagnostic module allow the larger patients to have an ultrasonic diagnosis and also allow the user to have a greater amount of computer support The ultrasonic module is linked to a computer system via a general-purpose interface. The sensor measures the sound burst flight time.Using this flight time and the sound speed $(1,126 \mathrm{ft} / \mathrm{s})$, a user then calculates the distance to an object.

Moisture Sensor: Since free soil moisture direct gravimetric measurement needs a sample to be removed, dried, and weighed. Soil humidity sensors indirectly evaluate volumetric water content using some other soil properties such as electrical resistance, dielectric constant, or neutron interaction[19],[21],[23].

GPS: A GPS route framework is a GPS beneficiary and parts for sound/video (AV) proposed for a specific reason, for example, a vehicle based or handheld gadget or a cell phone application. The worldwide situating framework (GPS) is a 24-satellite route framework that finds the spot of a beneficiary on Earth utilizing different satellite sign.

\section{IMPLEMENTATION}

A database will be retained containing the data by their respective ids about which dustbin to be placed in which region.Users will learn about the level of real-time trash from the information gathered, and the garbage collection van will be able to discover optimized path for garbage collection. The alert will be produced for emergency garbage collection whenever the trash level crosses the limit level.Data on the level of moist and dry segregation will assist evaluate present garbage management plans as well as refine plans to increase effectiveness. The easy Web GUI will assist the user efficiently use this scheme[20],[22],[24].

The IOT can alter the way waste collectors carry on their activities, learn more about their bins, and alter the waste collection technique. On the other side, consumers will be able to pay decreased premium and other associated expenses. In brief, in terms of procedures, the method of offering insurance, serving policy and settling claims will be much more effective and transparent.

One of IoT's primary ideas is to create it as effective as possible for users to control devices and save energy as they use them. Waste and recycling collectors are always looking at ways to minimize costs and boost productivity as far as possible when it comes to waste sector. This would mean better use of manpower, lowering the cost of the fleet and increasing productivity per capita while simultaneously automating what used to be a tedious method of collecting a fixed-route process. Public dustbins will be given in the suggested scheme with an embedded device that helps monitor the amount of trash in the garbage bins in real time[26],[28],[30].

\section{CONCLUSION}

We have created an effective waste management scheme in our article. Technology is used in metropolitan regions to provide better techniques of garbage disposal. We used sensors to show whether the containers were filled or empty. When a truck driver is filled in, a message is received to clean the bin.This scheme eliminates the present day status of the bins most of the moment deposited without being washed in a pathetic situation with regard to complete trash. We also created an Android application that allows the user to locate a bin close to him through the garbage. This generates a direct link where every citizen contributes to the maintenance of a clean atmosphere around him. A web server is also set up to provide the municipal authorities with data about the bins in their region as well.

\section{REFERENCES}

1. Gowri Sankaran, B., Karthik, B. \& Vijayaragavan, S.P. 2019, "Weight ward change region plummeting change for square based image huffman coding", International Journal of Innovative Technology and Exploring Engineering, vol. 8, no. 10, pp. 4313-4316.

2. Gowri Sankaran, B., Karthik, B. \& Vijayaragavan, S.P. 2019, "Image compression utilizing wavelet transform", International Journal of Innovative Technology and Exploring Engineering, vol. 8, no. 10, pp. 4305-4308.

3. Kandavel, N. \& Kumaravel, A. 2019, "Offloading computation for efficient energy in mobile cloud computing", International Journal of Innovative Technology and Exploring Engineering, vol. 8, no. 10, pp. 4317-4320.

4. Vinoth, V.V. \& Kanniga, E. 2019, "Reversible data hiding in encrypting images-an system", International Journal of Engineering and Advanced Technology, vol. 8, no. 6, pp. 3051-3053.

5. Selvapriya, B. \& Raghu, B. 2019, "Pseudocoloring of medical images: A research", International Journal of Engineering and Advanced Technology, vol. 8, no. 6, pp. 3712-3716.

6. Senthil Kumar, K. \& Muthukumaravel, A. 2019, "Bi-objective constraint and hybrid optimizer for the test case prioritization", International Journal of Engineering and Advanced Technology, vol. 8, no. 6, pp. 3436-3448.

7. Kavitha, G., Priya, N., Anuradha, C. \& Pothumani, S. 2019 , "Read-write, peer-to-peer algorithms for the location-identity split", International Journal of Innovative Technology and Exploring Engineering, vol. 8, no. 9 Special Issue 3, pp. 445-447. 
8. Kaliyamurthie, K.P., Michael, G., Anuratha, C. \& Sundaraj, B. 2019 "Certain improvements in alzheimer disease classification using novel fuzzy c means clustering for image segmentation", International Journal of Innovative Technology and Exploring Engineering, vol. 8, no. 9 Special Issue 3, pp. 599-604.

9. Kaliyamurthie, K.P., Sundarraj, B., Geo, A.V.A. \& Michael, G. 2019, "RIB: Analysis of I/O automata", International Journal of Innovative Technology and Exploring Engineering, vol. 8, no. 9 Special Issue 3, pp. 1019-1022.

10. Velvizhi, R., Rajabhushanam, C. \& Vidhya, S.R.S. 2019, "Opinion mining for travel route recommendation using Social Media Networks (Twitter)", International Journal of Innovative Technology and Exploring Engineering, vol. 8, no. 9 Special Issue 3, pp. 508-512.

11. Kavitha, R., Sangeetha, S. \& Varghese, A.G. 2019, "Human activity patterns in big data for healthcare applications", International Journal of Innovative Technology and Exploring Engineering, vol. 8, no. 9 Special Issue 3, pp. 1101-1103.

12. Pothumani, S., Anandam, A.K., Sharma, N. \& Franklin, S. 2019, "Extended VEOT framework - Implemented in a smart boutique", International Journal of Innovative Technology and Exploring Engineering, vol. 8, no. 9 Special Issue 3, pp. 762-767.

13. Kaliyamurthie, K.P., Michael, G., Krishnan, R.M.V. \& Sundarraj, B. 2019, "Pseudorandom techniques for the internet", International Journal of Innovative Technology and Exploring Engineering, vol. 8, no. 9 Special Issue 3, pp. 915-918.

14. Aravindasamy, R., Jeffrin Rajan, M., Rama, A. \& Kavitha, P. 2019, "Deep learning provisions in the matlab: Focus on CNN facility", International Journal of Innovative Technology and Exploring Engineering, vol. 8, no. 9 Special Issue 3, pp. 990-994.

15. Theivasigamani, S., Linda, M. \& Amudha, S. 2019, "Object sensing and its identification \& motion sensing", International Journal of Innovative Technology and Exploring Engineering, vol. 8, no. 9 Special Issue 3, pp. 545-549.

16. Mary Linda, I., Vimala, D. \& Shanmuga Priya, K. 2019, "A methodology for the emulation of IPv4", International Journal of Innovative Technology and Exploring Engineering, vol. 8, no. 9 Special Issue 3, pp. 848-852.

17. Velvizhi, R., Priya, D.J., Vimala, D. \& Linda, I.M. 2019, "Increased routing algorithm for mobile adhoc networks", International Journal of Innovative Technology and Exploring Engineering, vol. 8, no. 9 Special Issue 3, pp. 1606-1608.

18. Sangeetha, S., Anuradha, C. \& Priya, N. 2019, "DNS in real world", International Journal of Innovative Technology and Exploring Engineering, vol. 8, no. 9 Special Issue 3, pp. 937-940.

19. Geetha, C., Vimala, D. \& Priya, K.S. 2019, "Constructing multi-processors and spreadsheets with SKIVE", International Journal of Innovative Technology and Exploring Engineering, vol. 8, no. 9 Special Issue 3, pp. 516-519.

20. Yugendhar, K., Sugumar, V. \& Kavitha, P. 2019, "A novel method of univac using fuzzy logic", International Journal of Innovative Technology and Exploring Engineering, vol. 8, no. 9 Special Issue 3, pp. 435-437.

21. Kaliyamurthie, K.P., Michael, G., Elankavi, R. \& Jijo, S.A. 2019, "Implementing aggregate-key for sharing data in cloud environment using cryptographic encryption", International Journal of Innovative Technology and Exploring Engineering, vol. 8, no. 9 Special Issue 3, pp. 957-959.

22. Jeffrin Rajan, M., Aravindasamy, R., Kavitha, P. \& Rama, A. 2019, "A novel method of object orientation variation in $\mathrm{C}++$ and java", International Journal of Innovative Technology and Exploring Engineering, vol. 8, no. 9 Special Issue 3, pp. 708-710.

23. Nayak, R., Dinesh, S. \& Thirunavukkarasu, S. 2019, "A novel method improvement of rapid miner for the data mining applications", International Journal of Innovative Technology and Exploring Engineering, vol. 8, no. 9 Special Issue 3, pp. 457-460.

24. Sivaraman, K., Krishnan, R.M.V., Sundarraj, B. \& Sri Gowthem, S. 2019, "Network failure detection and diagnosis by analyzing syslog and SNS data: Applying big data analysis to network operations", International Journal of Innovative Technology and Exploring Engineering, vol. 8, no. 9 Special Issue 3, pp. 883-887.

25. Vimala, D., Linda, I.M. \& Priya, K.S. 2019, "Decoupling online algorithms from erasure coding in DNS", International Journal of Innovative Technology and Exploring Engineering, vol. 8, no. 9 Special Issue 3, pp. 950-953.

26. Rama, A., Kumaravel, A. \& Nalini, C. 2019, "Preprocessing medical images for classification using deep learning techniques", International Journal of Innovative Technology and Exploring Engineering, vol. 8, no. 9 Special Issue 3, pp. 711-716.
27. Sangeetha, S., Srividhya, S.R., Anita Davamani, K. \& Amudha, S. 2019, "A procedure for avoid overrun error in universal synchronous asynchronous receiver transmitter (usart) by utilizing dummy join and interrupt latency method", International Journal of Innovative Technology and Exploring Engineering, vol. 8, no. 9 Special Issue 3, pp. 657-660.

28. Aravindasamy, R., Jeyapriya, D., Sundarajan, B. \& Sangeetha, S. 2019, "Data duplication in cloud for optimal performance and security", International Journal of Innovative Technology and Exploring Engineering, vol. 8, no. 9 Special Issue 3, pp. 1156-1158

29. Aravindasamy, R., Jeffrin Rajan, M., Sugumar, V. \& Kavitha, P. 2019, "A novel method on developing superblocks and the transistor using apodryal", International Journal of Innovative Technology and Exploring Engineering, vol. 8, no. 9 Special Issue 3, pp. 982-985.

30. Sasikumar, C.S. \& Kumaravel, A. 2019, "E-learning attributes selection through rough set theory and data mining", International Journal of Innovative Technology and Exploring Engineering, vol. 8 , no. 10 , pp. $3920-3924$

\section{AUTHORS PROFILE}

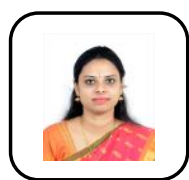

R.KrishnaBharathi Assistant Professor, Department of Computer science and Engineering, Bharath Institute of Higher Education and Research, Chennai, India

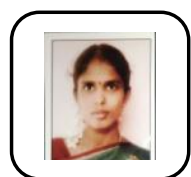

T. SelvaBanupriya Assistant Professor, Department of Computer science and Engineering, Bharath Institute of Higher Education and Research, Chennai, India

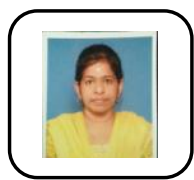

Jeyapriyanga S Assistant Professor, Department of Computer science and Engineering, Bharath Institute of Higher Education and Research, Chennai, India 